\title{
Relationship between facial morphology, anterior open bite and non-nutritive sucking habits during the primary dentition stage
}

Melissa Proença Nogueira Fialho¹, Célia Regina Maio Pinzan-Vercelino², Rodrigo Proença Nogueira ${ }^{3}$, Júlio de Araújo Gurgel ${ }^{4}$

DOI: $h t t p: / / d x$. doi.org/10.1590/2176-9451.19.3.108-113.oar

Introduction: Non-nutritive sucking habits (NNSHs) can cause occlusal alterations, including anterior open bite (AOB). However, not all patients develop this malocclusion. Therefore, the emergence of AOB does not depend on deleterious habits, only. Objective: Investigate a potential association between non-nutritive sucking habits (NNSHs), anterior open bite (AOB) and facial morphology (FM). Methods: 176 children in the primary dentition stage were selected. Intra and extraoral clinical examinations were performed and the children's legal guardians were asked to respond to a questionnaire comprising issues related to non-nutritive sucking habits (NNSHs). Results: A statistically significant relationship was found between non-nutritive sucking habits (NNSHs) and anterior open bite (AOB). However, no association was found between these factors and children's facial morphology (FM). Conclusions: Non-nutritive sucking habits (NNSHs) during the primary dentition stage play a key role in determining anterior open bite (AOB) malocclusion regardless of patient's morphological facial pattern (FM).

Keywords: Open bite. Face. Primary dentition.

Introdução: os hábitos de sucção não nutritiva podem causar alterações oclusais, como, por exemplo, a mordida aberta anterior (MAA). No entanto, nem todos os pacientes desenvolvem essa má oclusão. Sendo assim, a instalação da MAA não depende apenas da ocorrência do hábito. Objetivo: avaliar a possível associação entre hábito de sucção não nutritiva, mordida aberta anterior e morfologia facial. Métodos: foram selecionadas 176 crianças na fase de dentição decídua completa. Exames clínicos intra- e extrabucais foram realizados, e um questionário, com aspectos relacionados aos hábitos de sucção não nutritiva, foi aplicado aos responsáveis. Resultados: encontrou-se uma relação estatisticamente significativa entre as variáveis hábito de sucção não nutritiva e MAA. Entretanto, não houve associação desses fatores com a morfologia facial da criança. Conclusão: a presença dos hábitos de sucção não nutritiva tem associação para a determinação da má oclusão de MAA, independentemente do padrão facial morfológico na dentição decídua.

Palavras-chave: Hábitos. Mordida aberta. Face. Dentição primária.

${ }^{1}$ Professor, School of Dentistry, CEUMA Univeristy, UNICEUMA.

${ }^{2}$ Assistant professor, Department of Orthodontics, School of Dentistry, CEUMA Univeristy, UNICEUMA.

${ }^{3}$ Assistant professor, Brazilian Dental Association/Maranhão.

${ }^{4}$ Assistant professor, Department of Orthodontics, CEUMA University, UNICEUMA.

Submitted: April 03, 2013 - Revised and accepted: August 12, 2013
How to cite this article: Fialho MPN, Pinzan-Vercelino CRM, Nogueira RP, Gurgel JA. Relationship between facial morphology, anterior open bite and non-nutritive sucking habits during the primary dentition stage. Dental Press J Orthod. 2014 May-June;19(3):108-13. DOI: http://dx.doi.org/10.1590/21769451.19.3.108-113.oar

\footnotetext{
» The authors report no commercial, proprietary or financial interest in the products or companies described in this article.
}

Contact address: Célia Regina Maio Pinzan Vercelino

Alameda dos Sabiás, 58 - Portal dos Pássaros - Boituva/SP - Brazil

CEP: 18550-000 - E-mail: cepinzan@hotmail.com 


\section{INTRODUCTION AND LITERATURE REVIEW}

Much has been published about facial morphology (FM) analysis. ${ }^{1,2,3}$ Orthodontic diagnosis on children requires not only proper occlusal and model analyses, but also a thorough assessment of facial configuration for growth prediction. In most cases, growth assessment means advancing a prognosis and, as a consequence, reducing the need for a more complex treatment in future. ${ }^{4}$

Anterior open bite (AOB) is one of the most common malocclusions in the primary dentition, and non-nutritive sucking habits (NNSHs) are among its etiologic factors. ${ }^{1,5-9}$ Continuous thumb and pacifier sucking habits hinder proper teeth and alveolar processes development, especially in the anterior region. ${ }^{10}$

Long-facial morphology (dolichofacial) is closely associated with the development of $\mathrm{AOB}$ due to counterclockwise rotation of the mandible and consequent lip incompetence. ${ }^{10}$

$\mathrm{AOB}$ is the most prevalent malocclusion in primary dentition..$^{2,10-13}$ It is very often associated with the presence of NNSHs, ${ }^{6,7,8}$ however, it tends to self-correct when the habit is eliminated at an early stage. ${ }^{14}$

To this day, the effect of facial morphology (FM) on growing patients with complete primary dentition and NNSH is seldom found in the orthodontic literature. ${ }^{15}$ Most studies focusing on the association between facial morphology and $\mathrm{AOB}$ - with or without NNSH - consider patients in the mixed dentition stage. ${ }^{11,16,17}$

In 2004, Katz et $\mathrm{al}^{1}$ examined 4-year-old children in the primary dentition stage to assess the relationship between NNSHs, FM and malocclusions. The authors found no association between facial morphology and malocclusion.

Despite the strong correlation between NSSHs and $\mathrm{AOB},{ }^{18-22}$ not all children develop this malocclusion of which determinant factors are NNSHrelated (duration, frequency and intensity) as well as patient-related (alveolar resistance and growth pattern). In light of a notorious lack of studies focusing on patients in the primary dentition stage, the aim of this study was to test the null hypothesis that there is no relationship between facial morphology (FM), anterior open bite (AOB), and nonnutritive sucking habits (NNSH).

\section{MATERIAL AND METHODS}

This cross-sectional study was conducted with subjects randomly selected from a population of children attending elementary schools in the city of São Luís, Brazil. The sample comprised 176 children with primary dentition ( 96 females and 80 males) aged between 3 and 6 years old (mean age: 4.9 years, maximum age, 6.8 years and minimum age, 2.1 years). The sample was divided into two groups: Group 1 consisting of children with NNSHs, and group 2 comprising children without any history of NNSHs.

The following inclusion criteria were applied: Children in the primary dentition stage; presence of all primary teeth; absence of extensive caries; no significant anomalies of tooth shape or size; no history of previous orthodontic treatment; NNSH and nonNNSH patients. Additionally, children's legal guardians were required to sign an informed consent form. The exclusion criterion was the absence of the habit, only. This study was approved by the Institutional Review Board of CEUMA University under protocol no $00785 / 10$.

The study was conducted in three major phases. At first, school principals were presented with the permits issued by the City Health Department, the children were selected according to the inclusion criteria and a second meeting was scheduled with the guardians. Secondly, the children's legal guardians were provided with detailed information about the study, its purpose and how the children would be examined. Thereafter, an informed consent form was signed by those who agreed with the research. NNSH data were collected by means of a questionnaire answered by the children's legal guardians. The questionnaire was applied individually by the researcher herself. Thirdly, the study was geared towards examining the children both intra and extraorally by means of an individual clinical assessment. Intraoral examination was performed under natural light with the child positioned in front of the examiner with their dental arches positioned in centric relation. The examiner was previously calibrated and during clinical examination, had no access to the questionnaire that provided information about the children's sucking habits (blinded).

A flexible ruler was used to assess overbite. Measurements were taken from the incisal edge of the maxillary right central incisor to the incisal edge 
of the lower right central incisor. Children with negative overbite and linear measurement greater than $1 \mathrm{~mm}$ were deemed to have anterior open bite (AOB).

Extraoral examination was conducted to determine the children's facial morphology (short face, balanced face or long face). The Facial Morphologic ${ }^{23}$ index (FMI) was applied based on the ratio between morphological facial height (MFH) and bizygomatic distance (BD) established by means of the following formula: FMI $=$ MFH/BD. Morphological facial height was determined based on the linear distance between the nasion and gnathion, and the bizygomatic distance between the zygomatic points (Fig 1).

A digital caliper (Mitutoyo Digimatic Caliper 200mm/.0005 “- 8”; cat. No. 500 - 147B; Battery: SR44, serial number: BH012006 - Suzano - São Paulo - Brazil) was used for extraoral measurements. Based on the values obtained, children's facial morphology was then classified into short face $(<83.9)$, balanced face (84.0 to 87.9) and long face $(\geq 88.0){ }^{1,23}$

To ensure reliability, 36 children were randomly selected and re-assessed after 4 weeks. Numeric variables (bizygomatic distance, morphological facial height and overbite) were remeasured and the difference between the first and second measurements was determined. Dependent Student's t test was applied to assess the significance of differences observed between the two measurements, thereby revealing systematic error, according to Houston. ${ }^{24}$ To assess random error, Dahlberg's formula ${ }^{25}$ was employed $\left(\mathrm{Se}^{2}=\sum \mathrm{d}^{2} / 2 \mathrm{n}\right)$.

Qualitative variables were described by absolute (n) and relative (\%) frequencies. The overbite variable was described by mean and standard deviation.

To investigate the association between sucking habit and variable $\mathrm{AOB}$, sucking habit and facial morphology, as well as the association between FM, AOB and NNSH, chi-square test was applied. Additionally, when the smallest expected frequency was less than or equal to 5, Fisher's Exact Test was applied.

Relationships were also expressed by odds ratio with confidence interval set at 95\%.

One-way analysis of variance (ANOVA) was applied to compare AOB severity between the different facial types.

Level of significance was set at 5\% $(\mathrm{p}<0.05)$ for all tests. Statistical analyses were performed with Statistica version 5.1 software (StatSoft Inc., Tulsa, USA).

\section{RESULTS}

The error of the method results revealed reproducibility of measurements, since there were no systematic or random errors (Table 1 ).

A statistically significant association was found between NNSHs and the presence of AOB (Table 2). Nevertheless, there was no association between FM and AOB (Table 3).

Overall, children's FM showed no significant association with AOB malocclusion even in the presence of NNSHs. Children with balanced face and with NNSHs had the greatest percentages of AOB, followed by short-faced children (Table 4).

Among children with AOB, those with a short face had more severe anterior open bite, followed by those with a balanced face, and finally, a short face. No statistically significant difference was found between facial morphology and AOB severity (Table 5).

Finally, test power was applied, since no sample size calculation was performed at baseline to validate the results. Test power results showed that the study sample $(\mathrm{n}=176)$ had $80 \%$ power to detect a difference of 22 percentage points in the association test between two variables.

\section{DISCUSSION}

This study was conducted with a sample of children in the complete primary dentition stage, given that $\mathrm{AOB}$ malocclusions often occur during this period. Moreover, only a few studies have focused on this phase of occlusion development, since most researches associating habits with malocclusions focus on the mixed dentition stage. ${ }^{11,16,17}$ In addition, studies about facial morphology are scarce both in the mixed dentition and primary dentition stages, ${ }^{4}$ particularly those seeking to correlate facial morphology with the presence of non-nutritive sucking habits and anterior open bite. ${ }^{1}$

In Dentistry and other healthcare areas, there is an ongoing concern about the radiation doses applied to patients. Recent studies have been conducted to assess the acceptable doses employed in the different imaging methods ${ }^{26}$ with the purpose of reducing radiation in humans. Great emphasis has been given to facial analysis. Morphological facial index is a method used to classify facial patterns (facial morphology) without the need to expose the child to unnecessary radiation. 
Table 1 - Error of the method - results of paired t test and Dahlberg's formula. ${ }^{25}$

\begin{tabular}{|c|c|c|c|c|}
\hline Occlusal Indexes & $\begin{array}{l}1^{\text {st }} \text { Measurement } \\
\text { Mean } \pm \text { SD }\end{array}$ & $\begin{array}{l}2^{\text {nd }} \text { Measurement } \\
\text { Mean } \pm \text { SD }\end{array}$ & $p$ & Dahlberg \\
\hline Bizygomatic distance & $100.17 \pm 5.08$ & $100.11 \pm 5.14$ & 0.10 & 0.13 \\
\hline Morphological facial height & $84.32 \pm 3.88$ & $84.30 \pm 3.87$ & 0.26 & 0.08 \\
\hline Overbite & $0.58 \pm 2.65$ & $0.57 \pm 2.64$ & 0.25 & 0.04 \\
\hline
\end{tabular}

*Statistically significant: $p<0.05$

Table 2 - Association between non-nutritive sucking habits and anterior open bite.

\begin{tabular}{|c|c|c|c|c|c|c|}
\hline \multirow{2}{*}{ Groups } & \multicolumn{2}{|c|}{ N० AOB } & \multicolumn{2}{|c|}{$\mathrm{AOB}$} & \multirow{2}{*}{\multicolumn{2}{|c|}{ Odds ratio (IC 95\%) }} \\
\hline & $n$ & $\%$ & $n$ & $\%$ & & \\
\hline NNSH & 16 & 40.0 & 24 & 60.0 & 40 & \multirow{3}{*}{$\begin{array}{c}\text { Reference } \\
66.50(17.99-245.80)\end{array}$} \\
\hline No NNSH & 133 & 97.8 & 3 & 2.2 & 136 & \\
\hline Total & 149 & 84.7 & 27 & 15.3 & 176 & \\
\hline \multicolumn{7}{|c|}{$c 2=79.49 ; p<0.00^{*}$} \\
\hline
\end{tabular}

*Statistically significant: $p<0.05$

Table 3 - Association between facial morphology and anterior open bite.

\begin{tabular}{|c|c|c|c|c|c|c|}
\hline \multirow{2}{*}{ Morphology } & \multicolumn{2}{|c|}{ No AOB } & \multicolumn{2}{|c|}{$\mathrm{AOB}$} & \multirow{2}{*}{ Total } & \multirow{2}{*}{ Odds ratio (IC 95\%) } \\
\hline & $n$ & $\%$ & $n$ & $\%$ & & \\
\hline Short face & 56 & 84.8 & 10 & 15.2 & 66 & Reference \\
\hline Balanced face & 46 & 83.6 & 9 & 16.4 & 55 & $0.91(0.34-2.44)$ \\
\hline Long Face & 47 & 85.4 & 8 & 14.6 & 55 & $0.87(0.31-2.45)$ \\
\hline Total & 149 & 84.7 & 27 & 15.3 & 176 & \\
\hline \multicolumn{7}{|c|}{$c 2=0.07 ; p=0.96$} \\
\hline
\end{tabular}

*Statistically significant: $p<0.05$

Table 4 - Association between NNSHs, AOB and facial morphology

\begin{tabular}{|c|c|c|c|c|c|c|}
\hline Deleterious habit and facial & \multicolumn{2}{|c|}{ No AOB } & \multicolumn{2}{|c|}{ AOB } & \multirow{2}{*}{ Total } & \multirow{2}{*}{ Odds ratio (IC 95\%) } \\
\hline morphology & n & $\%$ & n & $\%$ & & \\
\hline NNSH and short face & 6 & 37.5 & 10 & 62.5 & 16 & Reference \\
\hline NNSH and balanced face & 5 & 35.7 & 9 & 64.3 & 14 & $0.93(0.21-4.11)$ \\
\hline NNSH and long face & 5 & 50.0 & 5 & 50.0 & 10 & $0.56(0.11-2.90)$ \\
\hline Total & 16 & 40.0 & 24 & 60.0 & 40 & \\
\hline \multicolumn{7}{|c|}{$c 2=0.57 ; p=0.75$} \\
\hline
\end{tabular}

*Statistically significant: $p<0.05$

Table 5 - Comparison among the three facial morphology patterns in terms of overbite in children with $\mathrm{AOB}$, expressed in $\mathrm{mm}$.

\begin{tabular}{lrl}
\hline & $\begin{array}{r}\text { Negative overbite } \\
\text { Facial morphology }\end{array}$ & $\boldsymbol{p}$ \\
\hline Balanced face & $-3.67 \pm 2.00$ & \\
Short face & $-4.80 \pm 1.75$ & 0.33 \\
\hline Long Face & $-3.63 \pm 2.00$ & \\
ANOVA: F $=1.15$ & & \\
\hline
\end{tabular}

*Statistically significant: $p<0.05$
For this reason, it was employed in the present study. It should be added that other studies ${ }^{1,2}$ with similar methods were also conducted in the primary dentition stage and previously published in the literature using morphological facial index.

Results yielded with children with non-nutritive sucking habits reveal a $60 \%$ occurrence of $\mathrm{AOB}$, which corroborates the values obtained by Sousa et $\mathrm{al}^{2}$ (63.4\%), 
but are nowhere near the values found by Katz et al ${ }^{1}$ (35.5\%). Other authors also found a positive relationship for the NNSH / AOB ratio..$^{6-8,19-21}$

Results revealed no association between facial morphology, NNSHs and AOB. It is speculated that, although NNSHs act as etiological factors of malocclusions, ${ }^{5-8}$ facial morphology does not interfere in this process as a facilitating factor in the emergence of this malocclusion during primary dentition. ${ }^{1}$

Katz et $\mathrm{al}^{1}$ reported that the different types of facial morphology and NNSHs produce independent effects on malocclusions. Among these is AOB which should therefore be studied separately. These authors ${ }^{1}$ endorse the idea that genetic factors seem to play a less important role than commonly believed, and that many types of malocclusions are actually acquired rather than inherited. However, Cozza et $\mathrm{a}^{11}$ refute this idea, stating that chronic non-nutritive sucking habits and the characteristics of facial hyperdivergence (long face) pose significant risks for the development of $\mathrm{AOB}$ when occurring together. It should be emphasized, however, that in the aforesaid study ${ }^{11}$ assessments were performed based on the cephalograms of children with a mean age of 9 years and 3 months, and in the mixed dentition stage, which differs from the sample used in the present study.

In this study, it was observed that among all children presenting with $\mathrm{AOB}, 14.6 \%$ had long face pattern, $15.2 \%$ short face, and $16.4 \%$ balanced face. Thus, the fact that patients with long face exhibited the lowest values in determining the onset of $\mathrm{AOB}$ shows an independent relationship between the presence of $\mathrm{AOB}$ and long face morphology, as well as other morphologies, in agreement with the results of Katz et $\mathrm{al}^{1}$ and Sousa et $\mathrm{al},{ }^{2}$ who applied a methodology that was similar to the one used in this study.

None of the types of facial morphology was prevalent, given that the values of $31.25 \%, 37.5 \%$ and $31.25 \%$ found for the balanced face, short face and long face, respectively, showed no statistically significant differences. This contrasts with the findings of Sousa et $\mathrm{al}^{2}$ and Silva Filho et $\mathrm{a}^{15}$ who argue that balanced face is the predominant pattern. It is believed that this difference in outcomes may be related to the fact that their investigation was carried out in different regions and in populations with different morphological characteristics.

With regard to the relationship between AOB severity and facial morphology, short-faced children exhibited the highest values of negative overbite, followed by balanced-faced, and long-faced children (Table 5). NNSH duration is of paramount importance in determining $\mathrm{AOB}$ emergence. ${ }^{19}$ The literature shows that factors such as NNSH duration, frequency and intensity affect $\mathrm{AOB}$ severity. ${ }^{17}$ This finding probably explains the higher values of negative overbite observed in short-faced children.

\section{CONCLUSIONS}

According to the methods applied in this study and after careful analysis of results, it seems reasonable to conclude that non-nutritive sucking habits (NNSHs) during the primary dentition stage play a key role in determining anterior open bite (AOB) malocclusion regardless of morphological facial pattern. 


\section{REFERENCES}

1. Katz CRT, Rosenblatt A, Gondim PPC. Nonnutritive sucking habits in Brazilian children: Effects on deciduous dentition and relationship with facial morphology. Am J Orthod Dentofacial Orthop. 2004;126(1):53-7.

2. Sousa RLS, Lima RB, Florêncio Filho C, Lima KC, Diógenes AMN. Prevalência e fatores de risco da mordida aberta anterior na dentadura decídua completa em pré-escolares na cidade de Natal/RNR. Rev Dental Press Ortod Ortop Facial. 2007;12(2):129-38.

3. Cabrera CA, Cabrera MC. Ortodontia clínica. Curitiba: Interativas; 1997

4. Proffit WR. Contemporany Orthodontics. 3nd ed. St Louis: Mosby; 2000.

5. Thomaz EBAF, Cangussu MCT, Assis AMO. Maternal breastfeeding, parafunctional oral habits and malocclusion in adolescents: a multivariate analysis. Int J Pediatr Otorhinolaryngol. 2012;76(4):500-6.

6. Furtado ANM, Vedovello Filho M. A influência do período de aleitamento materno na instalação dos hábitos de sucção não nutritivos e na ocorrência de maloclusão na dentição decídua. RGO: Rev Gaúch Odontol. 2007:55(4):335-41.

7. Leite-Cavalcanti A, Medeiros-Bezerra PK, Moura C. Aleitamento natural, aleitamento artificial, hábitos de sucção e maloclusões em pré-escolares brasileiros. Rev Salud Pública. 2007:9(2):194-204.

8. Oliveira AC, Pordeusb IA, Torresc CS, Martinsc MT, Paivab SM. Feeding and nonnutritive sucking habits and prevalence of open bite and crossbite in children/adolescents with Down syndrome. Angle Orthod. 2010:80(4):748-53

9. Mercadante MMN. Hábitos em Ortodontia. In: Ferreira FV. Ortodontia: diagnóstico e planejamento clínico. São Paulo: Artes Médica; 2004. p 253-79.

10. Forte FDS, Bosco VL. Prevalência de mordida aberta anterior e sua relação com hábitos de sucção não nutritiva. Pesq Bras Odonto Clin Integr. 2001:1(1):3-8.

11. Cozza P, Baccetti T. Franci L, Mucedero M, Polimeni A. Sucking habits and facial hyperdivergency as risk factors for anterior open bite in the mixed dentition. Am J Orthod Dentofacial Orthop. 2005;128(4):517-9.

12. Adair SM, Milano M, Dushku JC. Evaluation of the effects of orthodontic pacifiers on the primary dentitions of 24 to 59 month old children: preliminary study. Pediatric Dent. 1992;14(1):13-8.

13. Santana VC, Santos RM, Silva LAS, Novais SMA. Prevalência de Mordida Aberta Anterior e hábitos bucais indesejáveis em crianças de 3 a 6 anos de incompletos na cidade de Aracaju. J Bras Odontopediatr Odonto Bebe 2011;4(18):154-69.
14. Almeida RVD, Nogueira Filho JJ, Jardim MCAM. Prevalência de maloclusão e sua relação com hábitos bucais deletérios em escolares. Rev Pesq Bras Odontoped Clin Integr. 2002:2(1):43-5.

15. Silva Filho OG, Herkrath FJ, Queiroz APC, Aiello CA. Padrão facial na dentadura decídua: estudo epidemiológico. Rev Dental Press Ortod Ortop Facial. 2008;13(4):45-59.

16. Nisula KK, Lehto R, Lusa V, Nisula LK Varrela J. Occurrence of malocclusion and need of orthodontic treatment in early mixed dentition. Am J Orthod Dentofacial Orthop. 2003;124(6):631-8.

17. Tausche E, Luck L, Harzer W. Prevalence of malocclusions in the early mixed dentition and orthodontic treatment need. Eur J Orthod. 2004:26(3):237-44.

18. Moyers RE. Etiologia da má oclusão. In: Moyers RE. Ortodontia. 4a ed. Rio de Janeiro: Guanabara Koogan; 1991. p. 212-37.

19. Warren JJ, Bishara SE. Duration of nutritive and nonnutritive sucking behaviors and their effects on the dental arches in the primary dentition. Am J Orthod Dentofacial Orthop. 2002:121(4):347-56.

20. Diouf JF, Ngom PI, Badiane A, Cisse B, Ndoye C, Diop-ba K, Diagne F. Influence of the mode of nutritive and nonnutritive sucking on the dimensions of primary dental arches. Int Orthod. 2010;8(4):372-85.

21. Thomaz EBAF, Valença AMG. Prevalência de má-oclusão e fatores relacionados à sua ocorrência em pré-escolares da cidade de São Luís MA - Brasil. RPG Rev Pos Grad. 2005;12(2):212-21.

22. Tibolla C, Rigo L, Nijima LI, Estacia A, Frizzo EG, Lodi L. Associação entre mordida aberta anterior e hábito de sucção de chupeta em escolares de um município do sul do Brasil. Dental Press J Orthod. 2012;17(6):89-96.

23. Rakosi T, Jonas I, Grabe TM. Color atlas of dental medicine orthodonticdiagnosis. New York: Thieme; 1993. p. 108-9

24. Houston WJB. Analysis of errors in orthodontics measurements. Am J Orthod. 1983; 5(83):382-90.

25. Dahlberg G. Statistical methods for medical and biological students. New York: Intercience; 1940.

26. Grünheid T, Schieck JRK, Pliska BT, Ahmad M, Larsone BE. Dosimetry of a cone-beam computed tomography machine compared with a digital $x$-ray machine in orthodontic imaging. Am J Orthod Dentofacial Orthop. 2012:141(4):436-43. 